\title{
EFEKTIVITAS UNIT LAYANAN ADUAN SURAKARTA DALAM MENERIMA KELUHAN WARGA DI KOTA SURAKARTA
}

\author{
Is Hadri Utomo, Retno Suryawati dan Herwan Parwiyanto \\ Jurusan Ilmu Administrasi Negara, Universitas Sebelas Maret, Indonesia \\ ishadri@staff.uns.ac.id
}

\begin{abstract}
The establishment of the Surakarta Complaint Service Unit (ULAS) in 2013 as a non-structural government organization unit that carried out public complaints services. ULAS was formed to improve service quality and ensure the provision of public services in accordance with the principles of good governance, including the realization of public information disclosure in response to complaints from people who are not satisfied with the services they receive. This study examines the effectiveness of ULAS in accepting citizen complaints and the steps of the Surakarta City Government to follow up on these complaints, as well as solutions. All results state the existence of effectiveness, with some special notes on the conditions or variable questions that have answers that do not agree, among others concerning: the target of resolving citizen complaints by ULAS, complaints of citizens against certain problems have not been channeled to more than one OPD, solving problems against Complaints have also not fulfilled the satisfaction and aspirations of citizens, and related infrastructure facilities have not been in line with the development of information technology. Some of these are specific notes regarding the organizational effectiveness of ULAS.
\end{abstract}

Keyword: Effectiveness, ULAS, and Surakarta City

\begin{abstract}
ABSTRAK
Terbentuknya Unit Layanan Aduan Surakarta ( ULAS ) pada tahun 2013 sebagai unit organisasi pemerintah non struktural yang melaksanakan layanan pengaduan masyarakat. ULAS dibentuk untuk meningkatkan kualitas pelayanan dan menjamin penyediaan layanan publik yang sesuai dengan asas good governance, antara lain terwujudnya keterbukaan informasi publik dalam merespon pengaduan masyarakat yang merasa tidak puas dengan pelayanan yang diterimanya. Penelitian ini mengkaji efektivitas ULAS dalam menerima keluhan warga dan langkah Pemerintah Kota Surakarta menindaklanjuti keluhan tersebut, juga solusinya. Seluruh hasil menyatakan adanya efektifitas, dengan beberapa catatan khusus pada kondisi atau variabel pertanyaan yang terdapat jawaban yang tidak setuju, antara lain mengenai : target penyelesaian aduan warga oleh ULAS, aduan warga terhadap masalah tertentu belum dapat disalurkan kepada lebih dari satu OPD, pemecahan masalah terhadap aduan juga belum memenuhi kepuasan dan aspirasi dari warga, serta terkait sarana prasarana belum sesuai perkembangan teknologi informasi. Beberapa hal ini menjadi catatan khusus terkait efektifitas organisasi dari ULAS.
\end{abstract}

Kata Kunci: Efektivitas, ULAS dan Kota Surakarta

Diterima 19 November 2018; Diterima dengan revisi 15 Maret 2019; Dipublikasikan 1 Desember 2019 $2406-9515$ (p) / 2528-441X (e)

(C) 2019 David Adi Susilo, Retno Sunu Astuti, Budi Puspo Priyadi. Dipublikasikan oleh JAP FIS UNY 


\section{PENDAHULUAN}

Dalam suatu negara yang menganut sistem demokrasi kekuasaan tertinggi adalah di tangan rakyat, dan posisi pemerintah adalah sebagai pelayan masyarakat. Oleh karena itu maka sudah menjadi kewajiban pemerintah untuk memberikan pelayanan kepada publik secara baik dan memuaskan. Demikian juga negara Indonesia sebagai negara yang juga menganut sistem demokrasi, sudah selayaknya memberikan pelayanan yang baik dan memuaskan bagi warganya.

Namun pada kenyataannya sampai saat ini kualitas pelayanan yang dilakukan pemerintah kepada publik masih dirasakan kurang memuaskan. Hasil survei integritas yang dilakukan KPK (Komisi Pemberantasan Korupsi) menunjukkan bahwa kualitas pelayanan publik Indonesia baru mencapai skor 6,84 dari skala 10 untuk instansi pusat, dan 6,69 untuk unit pelayanan publik di daerah(www.bappenas.go.id). Hal ini masih mengindikasikan bahwa pelayanan kepada public dalam kategori sedang, dan hal tersebut ada kecenderungan rasa kekurang puasan masyarakat terhadap pelayanan yang diberikan oleh pemerintah.
Usaha perbaikan kualitas pelayanan kepada publik dapat terwujud jika ada dorongan dan partisipasi penuh dari masyarakat. Namun partisipasi masyarakat dalam menyampaikan aduan masih dalam katagori rendah, hal ini disebabkan karena sebagian besar masyarakat belum memahami bahwa dalam pelayanan publik terdapat hak masyarakat untuk menyampaikan keluhan atau masukan atas pelayanan yang diterima. Sebuah studi menunjukkan bahwa selama ini masyarakat lebih mengandalkan media surat kabar sebagai media yang dinilai masih paling efektif untuk bisa menyampaikan berbagai keluhan, yaitu sebesar 53.8\%. Posisi ini diikuti oleh radio $(33.91 \%)$ dan pesan singkat (SMS) sebesar $\quad 30.65 \%$. (http://www.bappenas.go.id/). Namun masyarakat juga acap kali enggan untuk melaporkan apa yang menjadi kekurangan atau kendala yang dihadapi dengan berbagai alasan seperti waktu yang terlalu lama untuk bisa menyampaikan pengaduan. (http://www.menpan.go.id/).

Kota Surakarta merupakan salah satu daerah yang telah menindaklanjuti kebijakan tersebut dengan menerbitkan Perwali No. 25 Tahun 2013 tentang Unit 
Layanan Aduan Surakarta (ULAS) yang merupakan wadah guna menangani pengaduan dan ketidak puasan masyarakat, baik yang menyangkut pelayanan publik maupun kebijakan. Pembetukan ULAS ini juga merupakan salah satu bentuk komitmen pemerintah kota Surakarta dalam meningkatkan kualitas pelayanan publiknya dengan memberikan kesempatan warganya untuk menyampaikan keluhan maupun aduan terkait pelayanan yang diberikan oleh pemerintah.

Ada beberapa sarana aduanyang bisa digunakan, yaitu sarana aduan nonelektronik dan sarana aduan elektronik. Sarana aduan non-elektronik (pengaduan secara langsung), mekanismenya yaitu, masyarakat (pengadu) menyampaikan secara langsung aduannya ke Kelurahan. Sedangkan sarana aduan elektronik mekanisnya yaitu pengadu dalam menyampaikan aduannya melalui sarana elektronik (Website, Twitter, Facebook, dsb). Penggunaan sarana aduan elektronik dapat meningkatkan kemandirian masyarakat dalam menyampaikan aduannya.

Namun demikian, meskipun sudah dibentuk ULAS sejak tahun 2014 sampai 2016, partisipasi masyarakat kota Surakarta dalam menyampaikan aduan masih rendah. Hasil penelitian Retno, Rino dan Herwan (2016) menemukan bahwa faktor penyebab rendahnya partisipasi tersebut karena minimnya sosialisasi yang berdampak pada rendahnya pengetahuan dan pemahaman masyarakat terkait dengan keberadaan ULAS termasuk prosedur pengaduannya. Padahal, Stoner (1982) menekankan pentingnya efektivitas organisasi dalam pencapaian tujuan-tujuan organisasi dan efektivitas adalah kunci dari kesuksesan suatu organisasi.

Sedangkan menurut Miller (1977: 292) mengemukan ektivitas dimaksud sebagai tingkat seberapa jauh suatu sistem sosial mencapai tujuannya. Efektivitas ini harus dibedakan dengan efisiensi. Efisiensi terutama mengandaung pengertian perbandingan antara biaya dan hasil, sedangkan efektivitas secara langsung dihubungkan dengan pencapaian suatu tujuan).

Sharma (1982: 314) memberikan kriteria atau ukuran efektivitas organisasi yang menyangkut faktor internal organisasi dan faktor ekternal organisasi yang meliputi antara lain :

1) Produktivitas organisasi atau output

2) Kemampuan organisasi dalam bentuk keberhasilannya menyesuaikan diri dari perubahan- 
perubahan didalam dan diluar organisasi

3) Tidak adanya ketegangan didalam organisasi atau hambatan-hambatan konflik diantara bagian-bagian organisasi

ULAS berdiri pada akhir tahun 2013 atas kerjasama antara pemerintah Kota Surakarta dengan Bandung Trust Advisory Group ( B-trust) yang didukung oleh Uni Eropa, dengan dilandasi dasar hukum Undang-undang Nomor 14 Tahun 2018 tentang: Keterbukaan Informasi Publik (KIP), Peraturan Presiden No.76/2013 tentang: Pengelolaan Pengaduan Pelayanan Publik, Per.Menpan No.5/2009 tentang: Pedoman Umum Penanganan Pengaduan Masyarakat Bagi Instansi Pemerintah. Berdasarkan pada Peraturan Walikota Surakarta Nomor 25 Tahun 2013 tentang: Unit Layanan Aduan Surakarta Pada Pemerintah Kota Surakarta; ditegaskan bahwa guna mewujudkan pemerintahan yang baik dan akuntabel diperlukan keterbukaan informasi publik yang merupakan sarana untuk mengoptimalkan partisipasi dan pengawasan publik dalam proses penyelenggaraan pemerintahan.

Reformasi birokrasi yang saat ini menjadi suatu keharusan bagi institusi publik; bertujuan untuk meningkatkan performa pelayanan publik kepada masyarakat agar menjadi lebih baik. Dalam dekade selama ini disinyalir bahwa kualitas pelayanan publik masih dalam kondisi yang sangat memprihatinkan. Hal ini disebabkan karena pemerintah selama ini belum dapat menyediakan kualitas pelayanan yang sesuai dengan kebutuhan dan perubahan situasi dan kondisi masyarakat. Rendahnya kualitas layanan kepada masyarakat tercermin dari banyaknya ungkapan rasa ketidakpuasan masyarakat atas pelayanan yang diterima selama ini.

Hasil survey integritas yang dilakukan oleh Komisi Pemberantasan Korupsi pada tahun 2013 menunjukkan bahwa kualitas pelayanan publik di Indonesia baru mencapai skor 6.71 dari skala 10 untuk instansi Pusat, dan 6,82 untuk unit pelayanan publik di daerah. Dilihat dari hasil skor integritas tersebut menunjukkan bahwa karakateristik kualitas dalam pelayanan publik dari sisi kebersihan suap, kesesuaian proses pelayanan dengan standard operating procedure (SOP), tingkat keterbukaan informasi, keadilan dan kecepatan dalam pemeberian pelayanan, serta kemudahan pengaduan masyarakat; masih dalam katagori sedang. Menurut studi yang 
dilakukan oleh Badan Perencanaan Pembangunan Nasional (Bappenas) pada tahun 2000, dinsinyalir salah satu hal yang memicu masyarakat enggan untuk menyampaikan keluhan/aduan kepada pemerintah; karena mereka tidak percaya bahwa pengaduannya akan segera ditanggapi dan ditindaklanjuti untuk dicari jalan pemecahannya.

Dalam menerima aduan yang disampaikan oleh masyarakat, ULAS berpedoman kepada beberapa kriteria aduan yang memuat hal hal sebagai berikut:

1. Aduan yang disampaikan oleh masyarakat hendaknya bersifat obyektif dan tidak mengarah pada fitnah, dan disertai data dan fakta yang dapat dipertanggungjawabkan.

2. Aduan yang disampaikan dapat menjelaskan siapa melakukan apa, kapan dan dimana subyek aduan melakukan hal tersebut

3. Menginformasikan adanya indikasi terjadinya suatu pelanggaran, penyimpangan, penyelewengan, penyalahgunaan wewenang, kesalahan yang dilakukan oleh aparatur terhadap penyelenggaraan pemerintahan.( Bandung Trust Advissory Group,2016 )
Efektivitas ULAS dalam penelitian ini dikaji dari lima (5) kriteria:

(1)Produktivitas organisasi atau output; yaitu suatu hasil kerja secara optimal yang telah dilakukan oleh ULAS dalam rangka menangani dan menindaklanjuti berbagai aduan warga yang telah disampaikan oleh warga pengadu.

Dalam pengertian ini ULAS mengkajii apakah aduan warga telah memenuhi persyaratan sesuai dengan ketentuan yang ada, yaitu bersifat obyektif tidak mengandung unsur fitnah, aduan menjelaskan subyek pengadu secara jelas, dan menginformasikan adanya suatu penyimpangan dalam penyelenggaraan pemerintahan. Selanjutnya aduan apakah sudah disalurkan secara tepat dan cepat kepada Organisasi Perangkat Daerah yang dituju, sampai kepada tindak lanjut ULAS dalam mempertanggungjawabkan aduan dari warga dengan cara memberikan informasi kepada pihak pengadu.

(2)Kemampuan adaptasi atau fleksibilitas, yaitu keleluasaan ULAS didalam menangani aduan warga yang dilakukan sesuai dengan kondisi permasalahannya, dan 
dipecahkan dengan cara yang luwes dan tepat sasaran

Pada tataran ini dikaji dari keleluasaan ULAS didalam menangani aduan warga yang disesuaikan dengan kemampuan para personilnya dalam menyelesaikan aduan secara variatif dari yang bersifat sederhana sampai dengan yang kompleks, juga dikaji dari inisiatif mereka untuk menyelesaikan aduan yang dapat disalurkan kepada lebih dari satu OPD untuk bisa diselesaikan secara multi fungsi yang memerlukan koordinasi antar OPD.

(3)Kepuasan pelanggan dan pemenuhan aspirasi, yaitu dampak dari hasil kerja optimal ULAS dalam menangani aduan warga pada tingkat kepuasan warga pengadu sesuai dengan aspirasi mereka.

Pada tataran ini warga pertamatama merasa senang dengan keberadaan ULAS, dan dengan keberadaan unit ini aduan dari warga ditanggapi dan dicarikan jalan keluarnya dengan baik sesuai dengan aspirasi mereka. Selanjutnya aduan warga juga telah ditindaklanjuti dengan cepat, dan ini hal ini menimbulkan kepuasan warga sehingga mereka lebih berani untuk menyalurkan aduan mereka kepada ULAS.

(4)Pengembangan Sumber Daya Manusia, adalah upaya ULAS dalam meningkatkan pengetahuan dan ketrampilan para admin dibidang teknologi informasi dalam rangka menyelesaikan tugas mereka yang berkaitan dengan aduan warga.

Hal ini diatandai dengan aktivitas ULAS dalam memprogramkan pendidikan dan latihan teknologi informasi bagi para admin yang disesuaikan dengan kebutuhan mereka, dengan harapan dapat meningkatkan pengetahuan dan ketrampilan para admin. Selanjutnya program pendidikan dan latihan teknologi informasi tersebut juga dilakukan secara rutin untuk penyegaran dan penambahan wawasan para admin, sehingga dapat menjadi bekal mereka dalam enyelesaikan aduan warga secara cepat.

(5)Tersedianya sarana dan prasarana, yaitu kesiapan ULAS dalam menyediakan berbagai fasilitas pendukung teknologi informasi dalam rangka menyelesaikan dan menindaklanjuti aduan warga. 
Dalam hal ini ditandai dengan program ULAS untuk merancang berbagai sarana dan prasarana teknologi informasi untuk melayanai warga yang dianggarkan secara rutin setiap tahun anggaran. Sarana dan prasarana ini sesuai dengan kebutuhan para admin dan mencukupi untuk melayani aduan warga, dan sesuai dengan perkembangan teknologi informasi.

\section{METODE}

Penelitian tentang Efektivitas Unit Layanan Aduan Surakarta Dalam Menerima Keluhan Warga Di Kota Surakarta ini dilakukan dengan cara observasi lapangan dan dengan metode Diskusi Kelompok Terarah ( Focus Group Discussion ). FGD telah dilakukan dengan cara menghadirkan / mengundang para aparat pemerintah kota Surakarta, yaitu Kepala Inspektorat Kota Surakarta, Super Admin ULAS, dan para Admin di tingkat Kelurahan. Kepala Inspektorat disini sebagai nara sumber didalam mngkoordinir dan mengangani kebijakan tentang pelaksanaan Unit Layanan Aduan Surakarta, yang dalam hal ini akan memonitor para aparatur Organisasi Perangkat Daerah didalam menindaklanjuti aduan warga masyarakat. Focus Group Discussion ( $F G D$ ) dilakukan dua kali, pertama mngundang para admin Kelurahan, dan yang kedua mengundang super admin Organisasi Perangkat Daerah untuk menggali pelaksanaan dilapangan yang berkaitan dengan aduan warga. Substansi dari FGD tersebut; pertama melakukan pelatihan para admin Kelurahan yang dilakukan oleh Tim Peneliti bekerjasama dengan Super Admin berkaitan dengan penanganan aduan warga, yang kedua melakukan pendalaman hasil lapangan dengan Super Admin Organisasi Perangkat Daerah berkaitan dengan proses penanganan aduan warga, dan tindak lanjut yang dilakukan oleh Organisasi Perangkat Daerah (OPD), serta kebijakan terkait dalam pengembangan ULAS.

Data yang terkumpul akan dianalisis dengan menggunakan model analisis interaktif dari Miles dan Huberman (dalam Denzin dan Lincoln, 1994) yang mencakup reduksi data, penyajian data, dan penarikan kesimpulan. Reduksi data merupakan proses seleksi, pemfokusan, penyederhanaan, dan abstraksi data kasar yang ada dalam catatan lapangan berkaitan dengan efektivitas ULAS dalam menerima keluhan warga. Data 


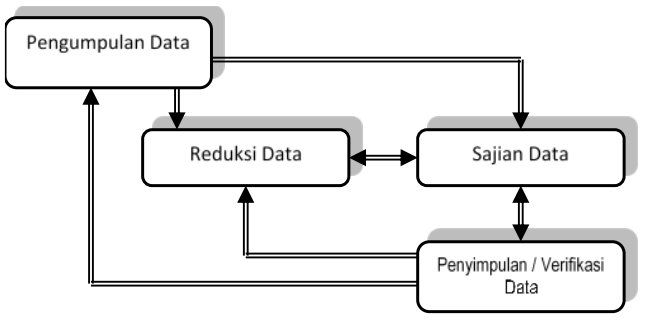

Sumber : Diadaptasikan dari Miles \& Huberman (1984).

dari lapangan yang berupa hasil wawancara atau rangkuman data sekunder yang ditranskripsikan dalam bentuk laporan kemudian direduksi dan dipilih hal yang menonjol. Penyajian data merupakan suatu rakitan organisasi informasi yang memungkinkan kesimpulan penelitian dapat dilakukan. Penyajian data akan menggunakan berbagai jenis matriks, gambar atau skema, jaringan kerja, keterkaitan kegiatan, dan tabel yang terkait dengan efektivias ULAS dalam menerima keluhan warga. Penarikan Kesimpulan merupakan suatu pengorganisasian data yang telah terkumpul sehingga dapat dibuat suatu kesimpulan tentang efektivitas ULAS. Peneliti bersikap terbuka dan skeptis. Kesimpulan yang pada awalnya kurang jelas kemudian meningkat secara eksplisit dan memiliki landasan yang kuat. Kesimpulan akhir tidak akan terjadi sampai proses pengumpulan data berakhir.

\section{HASIL DAN PEMBAHASAN}

Dalam penelitian ini didukung dengan beberapa pernyataan tertutup sebagai pancingan untuk mendapat respon dari para informan, dan juga disediakan pertanyaan terbuka untuk melengkapi pertanyaan tertutup tentang ULAS. Dalam FGD tersebut dibuka ajang tanya jawab/diskusi yang berkaitan dengan keluhan yang sering menimpa warga.

\section{Produktivitas Organisasi atau Output}

1.1. Aduan warga sudah sesuai dengan persyaratan yang ditentukan ULAS. Dari hasil kuesioner yang disebarkan, 45 informan $(83.3 \%)$ dari total 54 informan menyatakan setuju dan 6 informan $(11.1 \%)$ lainnya menyatakan sangat setuju. Secara keseluruhan berarti ada $94.4 \%$ aduan yang masuk ke sistem ULAS telah sesuai dengan persyaratan yang di tentukan.

1.2. Aduan warga di salurkan secara tepat kepada Organisasi Perangkat Daerah (OPD) yang berkompeten. Dari hasil kuesioner menunjukkan 38 informan (70.4\%) menyatakan setuju dan 13 lainnya $(24.1 \%)$ dari total 54 informan menyatakan sangat setuju. Mencapai $94.5 \%$ informan menyatakan bahwa aduan warga sudah di salurkan kepada OPD yang berkompeten terhadap adauan warga. 
1.3. Aduan warga diselesaiakan secara cepat oleh OPD yang bersangkutan, dari hasil yang diperoleh dapat di lihat bahwa 40 informan (74.1 \%) menyatakan setuju dan di dukung 9 informan lagi (16.7\%) menyatakan sangat setuju. Totalnya sebanyak 49 informan $(90.8 \%)$ dari total 54 informan menyatakan bahwa OPD yang bersangkutan telah menyelesaikan aduan dari warga masyarakat yang masuk ke ULAS.

1.4. Aduan warga diselesaikan tepat waktu oleh OPD sesuai masalah yang di adukan, hasil yang di dapat bahwa 36 informan (66.7\%) dari total 54 informan menyatakan setuju dan di tambah dengan 10 informan atau sekitar $18.5 \%$ menyatakan sangat setuju. Atau dengan kata lain sejumlah 46 informan (85.2 \%) menyatakan setuju bahwa penyelesaian dari OPD sesuai dengan masalah yang di adukan.

1.5. Penyelesaian aduan warga sesuai target ULAS, terdapat 42 informan $(77.8 \%)$ menyatakan setuju dan 2 informan (3.7 \%) menyatakan sangat setuju. Namun terdapat juga yang netral sebanyak 8 informan (14.8\%) dan juga 2 informan $(3.7 \%)$ yang tidak setuju. Jadi kesesuaian dalam target ULAS untuk di selesaiakan masih terkendala $18.5 \%$ dari ketercapaian target yang di harapkan.

1.6. Aduan warga di tindaklanjuti ULAS sampai tuntas. Dari 54 informan, terdapat 42 informan (77.8 \%) menyatakan setuju dan ditambah 7 informan (13\%) menyatakan sangat setuju. Dengan kata lain $90.8 \%$ menyatakan aduan dapat dengan tuntas di tindaklanjuti.

\subsection{ULAS}

mempertanggungjawabkan tugasnya kepada pejabat terkait. Terdapat sebanyak 41 informan (75.9 \%) informan menyatakan setuju dan ada 10 informan $(18.5 \%)$ menyatakan sangat setuju.

1.8. ULAS membuat laporan rutin kepada pejabat atasan. Ada 37 informan (68.5\%) menayatakan setuju dan 11 informan $(20.4 \%)$ menyatakan sangat setuju.

\section{Kemampuan Adaptasi atau Fleksibilitas}

2.1. Penanganan aduan warga di lakukan secara variatif sesuai kondisi permasalahan. Terdapat 48 informan (88.9 \%) menyatakan setuju dan ditambah 5 informan $(9.3 \%)$ menyatakan sangat setuju. Hampir semua menyatakan persetujuannya, 53 informan (98.2\%) dari total 54 informan admin ULAS.

2.1. ULAS menangani berbagai aduan warga dari yang bersifat sederhana 
sampai yang bersifat kompleks. Informan yang menyatakan setuju sebanyak 39 informan $(72.2 \%)$ dan juga ada sebanyak 11 informan ( $20.4 \%$ ) menyatakan sangat setuju.

2.3. Dalam penangan aduan warga di salurkan pada OPD dilakukan sesuai jenis aduannya. Ada 40 informan (74.1\%) menyatakan setuju dan terdapat 12 informan (22.2\%) menyatakan sangat setuju.

2.4. Aduan warga terhadap masalah tertentu dapat di salurkan pada lebih dari satu OPD. Yang menyatakan setuju ada 39 informan (72.2 \%) dan terdapat 4 informan $(7.4 \%)$ yang sangat setuju, namun ada juga yang tidak setuju sebanyak 4 informan (7.4\%) dari total 54 informan.

2.5. Pemecahan masalah aduan warga dapat di selesaikan secara multifungsi dari beberapa OPD. Terdapat 41 informan (75.9 \%) menyatakan persetujuannya dan 2 informan $(3.7 \%)$ menyatakan sangat setuju. Terdapat 1 informan $(1.9 \%)$ tidak setuju dan 10 informan $(18.5 \%)$ yang netral.

\subsection{Perlu koordinasi antar OPD} dalam menindaklanjuti aduan warga sampai tuntas. Dari informasi admin ULAS terdapat 29 informan $(53.7 \%)$ dan ada 19 informan (35.2\%) menyatakan sangat setuju. Yang tidak setuju ada 1 informan (1.9\%) dan yang netral ada 5 informan $(9.3 \%)$.

Kepuasan Pelanggan dan Pemenuhan Aspirasi

3.1. Warga masyarakat pengadu merasa senang dengan keberadaan ULAS. Terdapat 40 informan (74.1\%) menyatakan setuju dan ada 9 informan (16.7 \%) menyatakan sangat setuju, namun ada yang netral sebanyak 5 informan $(9.3 \%)$ dari total 54 informan.

3.2. Aduan warga yang ditangani ULAS di tanggapi secara baik oleh warga. Ada 46 informan (85.2 \%) menyatakan setuju dan 2 informan (3.7 $\%)$ menyatakan sangat setuju. Disamping itu ada 2 informan (3.7 \%) menyatakan tidak setuju dan yang netral ada 4 informan $(7.4 \%)$.

3.3. Warga pengadu merasa cukup puas dengan pemecahan masalah yang telah di lakukan ULAS. Terdapat 37 informan (68.5 \%) yang menyatakan setuju dan ada 2 informan (3.7\%) menyatakan sangat setuju. Sementara itu ada 4 informan $(7.4 \%)$ menyatakan tidak setuju dan ada 11 informan (20.4\%) menyatakan netral.

3.4. Aduan warga yang ditangani ULAS sudah sesuai dengan aspirasi 
warga. Yang menyatakan setuju ada 38 informan $(70.4 \%)$ dan ada 5 informan $(9.3 \%)$ menyatakan sangat setuju. Disamping itu ada sebanyak 10 informan (18.5\%) yang netral pendapatnya dan ada 1 informan (1.9\%) yang tidak setuju.

3.5. Sebagian besar aduan warga yang di tindaklanjuti ULAS sesuai dengan aspirasi yang di ajukan oleh warga. Terdapat 36 informan (66.7\%) menyatakan setuju dan ada 2 informan (3.7\%) yang menyatakan sangat setuju. Namun ada sebanyak 13 informan $(24.1$ $\%)$ yang netral dan ada 3 informan (5.6 $\%)$ yang tidak setuju.

3.6. Kepuasan warga pengadu dari hasil penanganan masalah yang telah terselesaikan dengan baik, menjadikan mereka lebih berani untuk menyalurkan aspirasi warga pada ULAS. Yang menyatakan setuju sebanyak 34 informan (63.0\%) ditambah dengan 12 informan (22.2 \%) menyatakan sangat setuju, sementara yang netral 8 informan (14.8 $\%)$.

\section{Pengembangan Sumber Daya Manusia}

4.1. ULAS memprogramkan beberapa pendidikan \& latihan teknologi informasi bagi para admin. Terdapat 37 informan $(68.5 \%)$ menyatakan setuju dan ada 10 informan (18.5 \%) menyatakan sangat setuju. Sementara itu terdapat 6 informan (11.1\%) menyatakan netral dan ada 1 informan (1.9\%) yang menyatakan tidak setuju.

4.2. Diklat teknologi informasi yang diprogramkan ULAS sesuai dengan kebutuhan para admin. Yang setuju ada 37 informan $(68.5 \%)$ dan yang sangat setuju ada 9 informan (16.7 \%), sementara itu yang netral ada 7 informan (13\%) dan yang tidak setuju ada 1 informan $(1.9 \%)$.

\subsection{Diklat teknologi informasi} yang dilakukan ULAS meningkatkan pengetahuan dan ketrampilan para admin. Terdapat 33 informan (61.1 \%) menyatakan setuju dan ada 17 informan (31.5\%) menyatakan sangat setuju. Serta ada 4 informan $(7.4 \%)$ yang netral.

4.4. Diklat teknologi informasi dilakukan secara rutin untuk penyegaran, penambahan wawasan, serta ketrampilan para admin. Yang menyatakan setuju ada 33 informan $(61.1 \%)$ dan yang sangat setuju ada 13 informan (24.1\%). Serta ada 6 informan (11.1\%) menyatakan netral dan ada 2 informan (3.7 \%) menyatakan tidak setuju.

4.5. Hasil diklat teknologi informasi menjadi bekal para admin dalam menyelesaikan aduan warga secara cepat. Ada 36 informan (66.7\%) 
menyatakan setuju dan di dukung 13 informan (24.1\%) menyatan sangat setuju, serta hanya 4 informan yang menyatakan netral $(9.3 \%)$.

\section{Tersedianya Sarana dan Prasarana}

5.1. ULAS merancang dan memprogramkan berbagai sarana dan prasarana teknologi informasi untuk melayani aduan warga. Ada 40 informan (74.1\%) yang menyatakan setuju dan ditambah dengan 6 informan (11.1\%) yang menyatakan sangat setuju. Di lain fihak ada 6 informan (11.1\%) yang netral dan ada 2 informan (3.7 \%) yang menyatakan tidak setuju.

5.2. Sarana dan prasarana teknologi informasi di anggarkan secara rutin setiap tahun anggaran. Ada 36 informan $(66.7 \%)$ yang setuju dan ada 7 informan (13\%) yang sangat setuju. Sebaliknya ada juga 9 informan (16.7\%) yang netral dan terdapat juga 2 informan (3.7\%) yang tidak setuju.

5.3. Sarana dan prasarana yang di anggarkan sesuai dengan kebutuhan pelaksanaannya. Hasil yang di dapat ada sebanyak 43 informan (79.6 \%) menyatakan setuju, dan ada 2 informan (3.7\%) sangat setuju. Sementara itu ada 8 informan (14.8\%) yang netral dan terdapat 1 informan $(1.9 \%)$ yang tidak setuju.

5.4. Sarana dan prasarana ULAS mencukupi untuk melayanai aduan warga masyarakat. Terdapat 41 informan (75.9 $\%)$ menyatakan setuju, dan ada 4 informan $(7.4 \%)$ yang sangat setuju. Di lain fihak ada 7 informan (13\%) menyatakan netral dan ada 2 informan (3.7\%) yang tidak setuju.

5.5. Sarana dan prasarana yang tersedia sudah sesuai dengan perkembangan teknologi informasi. Terakhir terdapat 38 informan (70.4\%) menyatakan setuju dan ada 8 informan (14.8\%) yang menyatakan sangat setuju. Serta 4 informan $(7.4 \%)$ yang netral dan 4 informan (7.4\%) juga yang tidak setuju.

\section{SIMPULAN}

Dalam era keterbukaan sekarang ini perlu dibentuk suatu terobosan baru sebagai upaya untuk mengantisipasi dan meningkatkan kualitas layanan. Tujuan daru penignkatan pelayanan ini adalah untuk menjamin penyediaan pelayanan publik yang sesuai dengan asas-asas tata kelola pemerintahan yang baik ( good governance dan good corporate governance ); serta untuk dapat merespon pengaduan dari masyarakat. Oleh karena 
itu maka diperlukan suatu wadah guna menangani pengaduan dan ketidak puasan warga masyarakat. Wadah yang dibentuk untuk menangani pengaduan tersebut dikenal dengan Unit Layanan Aduan Surakarta yang merupakan unit organisasi pemerintah non struktural yang melaksanakan layanan pengaduan masyarakat. Didalam penanganan pengaduan masyarakat; ULAS melakukan kegiatan yang dimulai dari penerimaan aduan, pencatatan, penelaahan, klaaarifikasi, penyaluran, tindak lanjut, pelaporan ,sampai pada pengarsipan atas pengaduan masyarakat tersebut.

Dari hasil analisis data telah menunjukkan adanya efektifitas ULAS, hanya saja ada beberapa catatan secara khusus dari informan yang memberikan masukan terhadap kriteria efektifvitas ULAS; antara lain mengenai : target penyelesaian aduan warga oleh ULAS berkaitan dengan durasi waktu penyelesaian, aduan warga terhadap masalah tertentu belum dapat disalurkan kepada lebih dari satu OPD karena tingkat pemahaman warga yang masih minim, pemecahan masalah terhadap aduan juga belum memenuhi kepuasan dan aspirasi dari warga karena ketidak pedulian warga terhadap tugas pokok dan fungsi, dan sarana prasarana teknologi informas yang belum sesuai seperti apa yang diharapkan ULAS.. Beberapa hal ini menjadi temuan penelitian dan menjadi catatan khusus berdasakan informasi dari para informan terkait efektifitas ULAS dalam menanggapi aduan warga Kota Surakarta.

\section{DAFTAR PUSTAKA}

Amir Syarifudin Kiwang, David B. W. Pandie, Frans Gana,,2015, Analisis Kebijakan dan Efektivitas Organisasi, Jurnal Kebijakan dan Administrasi Publik, Vol 19, No 1 https://journal.ugm.ac.id/jkap/articl e/view/7535

Armstrong, Michael. 1990. Manajemen Sumber Daya Manusia (Alih bahasa Ali Sofjan dan Haryanto). Jakarta: Elex Media Komputindo.

Azhar Kasim. 1989. Pengukuran Efektivitas dalam Organisasi. Jakarta: PAU Ilmu-ilmu Sosial UI.

B_Trust. 2016. Panduan Praktis Pembentukan Sistem Penanganan Pengaduan Masyarakat Di Daerah.

Bowman, C. 1990. The Essence of Strategic Management. Englewood Cliffs, New Jersey: Prentice Hall.

Burhan, N. 1989. Perencanaan Strategik. Jakarta, Pustaka Binaman Pressindo.

Devi Rachmawati. 2016. Penerapan Inovasi Pelayanan Pengaduan Media Center di dinas Komunikasi dan Informasi Kota Surabaya. Skripsi thesis, Universitas 
Airlangga.

http://repository.unair.ac.id/44035/ diakses tgl 11 Februari 2017.

Etzioni, Amitai. 1964. Modern Organizations. $\quad$ New Jersey: Prentice Hall.

Kast, F.E \& Rosenzweig, J.E. 1974. Organization and Management: A System Approach. New York: Mc Graw Hill Book Company.

Katz, D \& Kahn, R.L. 1966. The Social Psychology of Organization. New York: John Wiley \& Sons.

Lubis, Hari S.B \& Huseini, Martani. 1987. Teori Organisasi (Suatu Pendekatan Makro). Jakarta: PAU Ilmu-ilmu Sosial UI

Nurul Wahida Safitri .2016. Penerapan E-Government di Pusat Pelayanan informasi dan Pengaduan Kabupaten Pinrang. http://repository.unhas.ac.id/handle/ 123456789/17975. diakses tgl 10 Februari 2017.

Parkinson, C. Northcote. 1984. Parkinson's Law. New York: Ballantine Books.

Parsons, Talcott. 1951. The Social System. New York: The Free Press.

Peraturan Walikota Surakarta No. 25 Tahun 2013 tentang Unit Layanan Aduan Surakarta (ULAS)

Perrow, Charles. 1979. Complex Organizations: A Critical Essay. $2^{\text {nd }}$ ed. Glenview, 11. : Scott, Foresman \& Comp.

Peters, Thomas J. Waterman, Robert H. 1982. In Search of Excellence: Lesson from America's Best Run
Companies. New York : Harper \& Row, Pub.

Retno, Rino dan Herwan. 2016. Analisis Efektivitas Implementasi Kebijakan Unit Layanan Aduan Surakarta Pada Pemerintah Kota Surakarta. Laporan Penelitian Mandiri.

Richard \& Arthos, A. 1981. The Art of Japanese Management. Boston: Simon \& Schuster

Tim Direkotrat Aparatur Negara. Manajemen Pengaduan Masyarakat Dalam Pelayanan Publik.http://www.bappenas.go.id/f iles/4013/7637/9049/Manajemen_P engaduan_Masyarakat_Dalam_Pela yanan_Publik.pdf diakses tgl 10 Februari 2017.

Undang-Undang No. 25 Tahun 2009 Tentang Pelayanan Publik

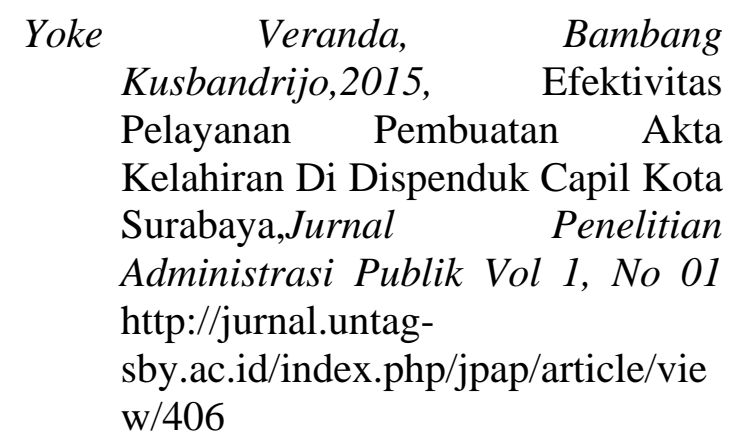

